\title{
"Saturated with Vice": Angelic White Children, Incorrigible Youth, and Re- formable Subjects
}

\author{
Hannah Anneliese Bailey
}

In 1937, Kansas's first female state representative to US Congress Kathryn O'Loughlin McCarthy learned that the Girls' Industrial School in Beloit, Kansas, the state's youth reformatory for girls, had sterilized over 60 school residents, sometimes against the wishes of the student's parents or guardians. The Girls' Industrial School was one of several state institutions where sterilization procedures were legally sanctioned in 1913, but newspaper accounts drew widespread condemnation of the school. Sensationalist paper the New York Daily News published several stories in October 1937 about the sterilization campaign, detailing parents' protests as well as an account of the doctor who performed the sterilizations. ${ }^{1}$ Despite the fact that sterilizations were legally authorized, McCarthy expressed horror that "sterilization was done for punishment rather than for any special good for society." While the media drew much-deserved attention to the unjust nature of institutional abuse and the sterilization of young girls, newspaper accounts normalized the practice at other institutions across the state, where victims were portrayed as wholly deserving of state interference in their reproductive processes.

In 1937, cultural anxieties surrounding criminality and white girlhood fueled these media representations of sterilization. Kansas state documents reveal how femininity was simultaneously feared and protected at state institutions. The 19151916 biennial report of the Board of Control of the State Charitable Institutions of Kansas claimed "statistics show that a feeble-minded woman is three times as likely to find a mate as a feeble-minded man, and also that feeble-minded women are ruthlessly pursued by evil-minded men." ${ }^{\prime 3}$ I argue that state deprivations of reproductive rights through allegations of mental inferiority or designations such as "feeblemindedness" were, in part, a reaction to societal fears about women's increased access to self-ownership and property ownership through formal voting rights. In the US, liberal categories of personhood were rooted to the material conditions of ownership. ${ }^{4}$ While enslaved Africans and African Americans were precluded from self-ownership by virtue of their condition of enslavement, white women maintained access to civil protections despite being denied formal property rights. ${ }^{5}$ This began to change as white women's access to liberal categories of ownership and individuality were expanded via voting rights. In Kansas, women gained the right to vote in 1912. The same upper-class white women who championed for their right to vote also advocated for more stringent laws governing institutional- 
ization and sterilization. ${ }^{6}$ Such laws ensured that while "sexually deviant" women may have been granted the right to vote, the liberal eugenic state would not allow them to produce offspring who would as well.

The 1937 media scandal in Kansas, while occurring within the bounds of the law, replicated the contradictory understandings of white womanhood that were at play in the early to mid-twentieth century. The crisis unfolded in the 1930s, a period in which Wendy Kline argues that approaches to sterilization shifted away from the early twentieth-century goal of eliminating inherited deficiencies, to identifying and addressing the environmental factors that led to declining birth rates amidst the Great Depression. ${ }^{7}$ Newspaper accounts show how thoroughly many members of the public believed that sterilization laws were a mechanism to protect the institution of innocent white girlhood, while the liberal eugenic state made it clear that it saw the laws as a way to protect white motherhood from degradation. State documents further provide evidence for the claim that femininity was simultaneously feared and in need of protection.

In what follows, I provide the historical background of the Girls' Industrial School in Beloit to contextualize how representations of girlhood in reform institutions impacted later portrayals of sterilization amidst the 1937 media scandal. Next, I provide a brief history of sterilization law in Kansas before discussing the sterilized subject in Kansas' legal and cultural imaginary. ${ }^{8} \mathrm{I}$ demonstrate how anxieties surrounding criminality and white girlhood fueled a conversation about sterilization that became the subject of widespread state and national attention after the abuses at the Girls' Industrial School were uncovered. Finally, I return to the Girls' Industrial School to discuss how the racialist portrayals of inherent criminality of black girls and girls of colour within the school reveal the institution's understanding of white girlhood as ultimately reformable against racialized populations in the school. Sarah Haley argues that "the carceral system exposed and enforced the radical otherness of the Black female subject, thereby solidifying white women's particular gender formation." It is for that reason that a discussion of the sterilization scandal at the Girls' Industrial School also necessitates an interrogation of how white girlhood was constructed against racialized criminality within the institution. $^{10}$

\section{The Kansas Girls' Industrial School}

By the time the Girls' Industrial School made national headlines in 1937, it had already endured a long and fraught history. The institution in Beloit was established in 1888 with funds collected by the Women's Christian Temperance Union of Kansas for "girls who are in danger of being led into paths of vice and whose natural guardians are unworthy of the trust given to them." ${ }^{.11}$ Its time as a private institution was short-lived; the school was taken over by the State of Kansas a year later in 1889. The Girls' Industrial School then became one of ten "institutions for the benefit of the insane, blind, and deaf and dumb, and other such benevolent in- 
stitutions as the public good may require."12 The school, which served the entire state of Kansas, operated as a single-sex carceral institution for well over a century, with the Beloit Juvenile Correctional Facility finally closing in August 2009.

At the time of the school's establishment, Beloit had a population of $2,455 .{ }^{13}$ The site was chosen for the Girls' Industrial School due to its proximity to the railroad, but also because of its relative isolation from urban areas. ${ }^{14}$ Historically, Beloit and surrounding Mitchell County had always been overwhelmingly white. The 1940 census, taken just three years after the sterilization scandal broke, lists Mitchell County, Kansas as having only twenty people living in the county categorized as "negro," four categorized as "other races," and 11,315 people categorized as "white."15 Beloit's response to the influx of Black Exodusters into Kansas in the late 1870 s provides insight into the mechanisms of white supremacy of the small town. The Beloit Gazette reported, in graphically racist language, that the Beloit City Council took the extreme step of passing an ordinance in May 1879 that banned Black "refugees" from the south. ${ }^{16}$ It is not clear how long this law stayed on the books, if at all, but its mere mention reveals the extent of racist policing in the town. ${ }^{17}$

Despite the racism of the surrounding area, there is evidence of racial integration at the Girls' Industrial School as early as 1896, when 11.7 percent of girls at the school were "colored." 18 Several decades later the percentage of inmates of colour rose; the 1902-04 biennial report stated that 32 of the 160 girls at the school were designated "colored." ${ }^{19}$ At the time of the sterilization scandal, the school was mostly white, with ten "Negro" and two "Indian" students out of 98 listed. ${ }^{20} \mathrm{Al}$ though the school was historically a predominantly white institution situated in rural Kansas, racialized logics haunt the notion of criminality from its earliest days. ${ }^{21}$ While the school was integrated, Black students and other students of colour experienced segregation within the school, and archival records provide glimpses into experiences for Black students. The 1926-1928 biennial report includes a series of photos from the "America, the Beautiful Pageant." Large groups of girls in elaborate matching costumes are depicted as happy and easygoing in scenes such as "Colonial Days," "Kansas Sunflowers," and the surprisingly glamorous "Corn." On the other hand, Black children are absent from these photos until the very last page of the report, where one photo shows a group of apparently Black children as well as other children of colour, most in plain dresses and head scarves, with two wearing pants and bowties. One child sits while holding a banjo. The photograph is captioned "Plantation Scene." 22 The sections below will detail more fully how white supremacist understandings of girlhood influenced segregation and reform programs within the school, but this photograph reveals that while girls of colour may have been present at the school, they were not afforded the same opportunities as white students.

Societal understandings of sexuality, disability, and criminality comingled to create a unique experience of oppression for girls at single-sex reform institutions 
in the twentieth century. Like other such schools across the nation, the existence of the Kansas Girls' Industrial School was justified as a sympathetic effort to help "fallen" women, but always existed as a carceral space where girls were sent against their will. The selection of an isolated location for the girls' reformatory was influenced by eighteenth-century prison reform movements led by individuals like Benjamin Rush who espoused the belief that "isolation from the evils of the city, separation from the influence of their family and vice-ridden associates, and longterm treatment in a secure setting were all thought indispensable to root out the offending deviancy, whatever its form.."23 However, while these institutions hoped to reform deviant behaviour, they simultaneously existed to segregate those whose criminality was believed to be rooted in their inherited cognitive disability. Michael Rembis explains how "the biologization of social deviance ... created a lasting impression within American society of the socially 'dangerous' and morally 'corrupting' mentally 'ill'.'24

Contradictory societal understandings about "fallen" working-class girls led reformers to advocate for the establishment of separate reform institutions for young women. There simultaneously existed a fear that oversexualized girls tempted and corrupted young men and a sympathetic understanding that these women were victims of their biology and lower-class upbringings. Though eugenicist ideas about inherited degeneracy might seem to suggest that criminalized girls were beyond saving, there was still hope in the notion that proper education might allow for these girls to learn the skills necessary for marriage or low-level labour. Progressive-era movements sought to control the sexual behaviours of working-class women, and "urged Americans to resist the sexualization of female adolescence and thus to save disadvantaged young women and their communities from the 'living death' of prostitution." 25 Female sexuality needed to be segregated and isolated from society, as males who had premarital sex were portrayed as victims of irresistible forces. The state's anxieties about motherhood and femininity drove the decision to institutionalize and sterilize many "feeble-minded" women. The popular category of supposed degeneracy was quite often associated with girls' perceived oversexualization; in simpler terms, any evidence of girls' sexual drive before marriage could be grounds for commitment or sterilization. This association between perceived hypersexuality and mental inferiority in girls was largely reserved for non-white girls and workingclass girls. ${ }^{26}$

The designation of the girls' reformatory as an "industrial school" was in keeping with the nineteenth and early-twentieth century belief that wayward youth could only be reformed through labour. Black students at places like Hampton Agricultural and Industrial School in Virginia and Indigenous students at places like the Carlisle Industrial Indian School in Pennsylvania and Haskell Institute in Lawrence, Kansas adhered to the belief that racialized and criminalized populations could be reformed through labour. ${ }^{27}$ Discussing Booker T. Washington's promotion of industrial education, Roderick Ferguson explains how in Black institutions, industrial 
education "would play a crucial part in reforming the Black subject from degenerate and immoral primitive to the normative citizen-subject of the United States." ${ }^{28}$ Designating reform institutions as "industrial" across the US and beyond reveals the extent to which a belief in the regulatory role of work discipline worked in tandem with bodily and mental harm in these institutions that supposedly existed to help children. ${ }^{29}$

For girls' schools, industrial labour was thought to be necessary to divert students' energies away from sexual activities. Ruth Alexander explains how "reports and tracts issued by urban vice commissions...stress[ed] disadvantaged young women's selfish individualism, their disregard for hard work, and their enthusiastic participation in immoral relations." 30 If girls could be kept busy learning practical work skills then they would not have any spare time for immoral activities. Practically speaking, this model also meant that the students could perform the work necessary for maintaining the institution, like gardening and mending clothes. The Girls' Industrial School's third biennial report in the late 1880s illustrates the school's position, saying that "as idleness and a love for luxurious surroundings are at the root of much of the vice and crime in our American girls, the first and essential factor in reclaiming them is the proper assignment of industrial employment." 31 The belief that girls' sexual behaviour could be diverted through work was present at the school at least as late as 1945. In an interview with a state citizen's commission investigating abuse at the Girls' Industrial School that year, Tracy Mitchell Thompson, the "house manager" of the school's only racially segregated resident cottage, explained that “my children don't go to bed until 9 o'clock because I want them to be well worn out when they go to bed... because if that energy is not worked off it certainly goes into sexual vice, and I don't have that and won't have."32

While the first child labour law in Kansas was passed in 1905 to restrict the age under which children could work in meatpacking factories, forced labour was one of the only avenues that girls had to access reformability and some semblance of self-ownership beyond the institution. In 1933, Kansas Governor Harry $\mathrm{H}$. Woodring convened a commission to investigate the conditions and practices of the state public welfare institutions and discovered that upon parole-in the rare cases that it did happen-former Girls' Industrial School residents were often used as domestic servants in nearby homes. The report tells of one case where a student "was paroled to a home where she was apparently employed solely as a means of providing her foster-home with a cheap servant. No evidence could be found of her being given either adequate supervision or provided with suitable recreational amusements." 33 Therefore, girls could not leave the school unless they accepted conditions of servitude and some semblance of being "owned" by a local family. The same phenomenon occurred in Virginia, as the plaintiff in the US Supreme Court case Buck v. Bell, Carrie Buck, was not able to leave the Colony for Epileptics and Feeble-Minded — even after being sterilized — until a local family agreed to take her in as a domestic servant. ${ }^{34}$ 


\section{Sterilization in Kansas}

When the story broke about the sterilization scandal at the reformatory in Beloit, a Los Angeles Times article revealed McCarthy's horror at discovering what she believed to be a misapplication of the practice. The same article, however, also detailed a state sterilization board member's assertion that they "had followed a state sterilization law in effect for many years." 35 This is true-eugenicist laws legalizing sterilization at state institutions were initially passed in Kansas in 1913 and updated in 1917 and 1923. Beloit's 1934-36 biennial report, the one preceding the scandal, quotes the updated 1923 sterilization statute in full, including the provision that performing sterilizations "shall not render the board of examiners, its members or any person participating in the operation liable either civilly or criminally." 36 The same biennial report took a self-congratulatory tone when it noted that only a few residents did not fully consent to sterilization, saying that "very few protests [were] made at the three hearings of the board of examiners." 37 While this report seemed to celebrate the success of the procedures at the school, the following 1936-38 biennial report — after the sterilization scandal broke-made no mention of sterilization.

Kansas's history of coerced sexual sterilization predates statutes regulating such procedures. In an unprecedented case of institutional misconduct that Mark A. Largent calls "the most widely criticized use of sexual surgery in the late nineteenth century," 38 the superintendent of the Institute for Idiotic and Imbecile Youth in Winfield, Kansas, F. Hoyt Pilcher, took it upon himself to perform "asexualization" surgeries on at least 11 residents of the school. ${ }^{39}$ A scathing newspaper article in the Wichita Star on September 1, 1894 indicated opposition to Pilcher's sterilization campaign on both moral and political terms. It alleges that Pilcher was enacting a populist agenda upon the members of society most in need of protection. Indicating public opinion toward sterilization by at least some Republicans at the turn of the century, the article writes that "Dr. Pilcher has committed the most atrocious mutilations upon eleven of the inmates of the asylum. A mutilation which is regarded in law and public conscience as the most horrible that can befall a human being." 40 In the years following Pilcher's surgeries, a subsequent Winfield Superintendent named F.C. Cave published a short study of the sterilization victims who remained at the institution in 1914 - fourteen girls and forty-four boys. Although many members of the public had reacted negatively when learning about sterilization at the school, Cave maintained that the surgeries were beneficial for society. His report emphasized the extent to which the surgeries would both prevent future offspring as well as remove sexual desire, even if that came at the cost of mutilation. ${ }^{41}$

The first sterilization statute in Kansas, chapter 305, was passed by the state legislature in 1913 as "an act to prevent the procreation of habitual criminals, idiots, epileptics, imbeciles, and insane." ${ }^{42}$ In order to prevent procreation, the statute ordered state mental institutions to examine all residents to determine their fitness 
for procreation, and to send those recommendations to "the district court or any court of competent jurisdiction in and for the district from which such inmate or inmates has been committed to such institution or institutions." 43 The clunky lang uage and unclear criteria for determining who could be sterilized prevented institutions from enforcing the law. The sixth biennial report of the Combined Kansas Reports says that the law was "inoperative on account of the costs and the legal machinery attached to it." "In the 1922 Eugenical Sterilization in the United States, prominent US eugenicist Harry Laughlin compiled all known information about sterilization laws across the United States. The book includes excerpts from Laughlin's correspondence with the heads of Kansas institutions, some of whom critique the "red tape" surrounding sterilization laws and argue that superintendents deserved more autonomy in carrying out the procedures. Dr. L.R. Sellers, the superintendent of Larned State Hospital in Kansas, wrote candidly in a 1918 letter about his disdain for the fact that courts had to be involved in the process of sterilization. Applying the logic of eugenics to the process of jury selection itself, Sellers complained that to carry out the law "the superintendent would appear before a jury (often summoned from the livery stables and court house loafers). This jury of incompetents would hear the evidence that the superintendent gave, then pass upon it." 45 Because institutional administrators claimed to know best about who needed procedures and why, any intrusion or oversight into sterilization by average, and supposedly less than intelligent, citizens prevented the state from carrying out its eugenics program fully. For this reason, Sellers sarcastically concludes "you can readily see how enthusiastic the superintendents would be in complying with the law." 46

The revised 1917 Kansas statute mandated that, rather than send the sterilization cases to the court, they would be heard before an "examining board" consisting of the "chief medical officer of any subject institution, governing board of institution, and secretary of the state board of health." ${ }^{47}$ However, the updated law did not immediately lead to the widespread usage of the procedures. In an unpublished manuscript about sterilization in the US, research scientist Julius Paul explained that before 1921 there had been 54 sterilizations in Kansas, and then from 1925-1928 alone there were over 300 sterilizations across Kansas institutions. ${ }^{48} \mathrm{He}$ called the 1927 US Supreme Court decision in Buck v. Bell a "turning point" for sterilization law in Kansas, as it was only a year later that the issue made its way to the Kansas Supreme Court in the 1928 State v. Schaffer case. In his decision, Judge Rousseau Angelus Burch contended that the well-being of society ultimately trumped individual rights when it came to potentially "defective" people procreating. He argued that "reproduction turns adversary and thwarts the ultimate end and purpose of reproduction. The race may ensure its own perpetuation and such progeny may be prevented in the interest of higher general welfare." ${ }^{49}$ The state then sought to expand its power to control reproduction because when used in an "adversarial" manner it could harm society as a whole. Following the trial, sterilizations 
increased exponentially in Kansas_-between 1932 and 1942 there were nearly 2,000 sterilizations in Kansas. ${ }^{50}$

In reading Kathryn O'Loughlin McCarthy's papers and correspondence regarding the sterilization scandal at the Girls' Industrial School, it is evident that she-and many who corresponded with her-regarded the abuses perpetrated against the girls at Beloit as more egregious than those committed against any of the other thousands of victims of sterilization at the other Kansas State hospitals. Inspired by McCarthy's crusade against the sterilizations in Beloit, the Franklin D. Roosevelt Club in Kansas City, Kansas passed a resolution in November 1937 condemning the procedures on the grounds that the Girls' Industrial School "is not a penal institution, but a correctional institution of the state." ${ }^{51} \mathrm{Mr}$. John A. Johnson of Seattle, Washington echoed this outrage in a letter to McCarthy. Equating the ability to procreate with sexuality in general, Johnson wrote that "with proper training the majority of girls in these institutions eventually marry and become useful citizens. This operation not only deprives girls of the steadying influence of marriage but even acts as a very effective barrier to any married life at all."52

While these reactions to the sterilization scandal were critical of the ways that procedures were used punitively at Beloit to deprive girls of the benefits of motherhood, many still held that there were some individuals who may have been deserving of the procedure. Although the superintendent who approved the sterilizations, Lula Coyner, received widespread condemnation for her role in the sterilization campaign as well as for her treatment of students in general, Coyner's approach to sterilizations may not have differed from previous superintendents at the school who may have used the procedures if there were not bureaucratic difficulties involved in the process. In prominent pseudoscientist and eugenics proponent Harry Laughlin's correspondence with the superintendents of institutions that could practice sterilization according to the 1913 law, a former superintendent of the Girls' Industrial School, Lillian M. Mitchner, wrote of sterilization that "it seems to me that if it were enforced in our institutions for feeble-minded and subnormal men and women, boys and girls, it would be of incalculable value along eugenical lines." 53 Mitchner's position reveals the extent to which sterilization was normalized within the institutional state bureaucracy despite sometimes appearing abhorrent to the public and even politicians like McCarthy.

The scandal at the Girls' Industrial School reveals the extent to which conceptions of sexuality were always linked to understandings of race and criminality. Laughlin wrote when discussing venereal disease laws, "the great majority of women who marry are pure, while a considerable amount of men have had illicit sexual relations before marriage." 54 Because men were thought to have more "natural" inclinations toward sexual behaviour, their premarital sexual relations did not induce the same level of societal anxiety as women who deviated from their "pureness." Those women who did show evidence of sexual behaviour before marriage, particularly those from poorer backgrounds, were largely blamed for producing criminal 
offspring. ${ }^{55}$ This speaks to the inconsistency between the public's outrage toward sterilization being used punitively to deprive white girls of the opportunity to become mothers and eugenicist views of unwieldy female sexuality as the ultimate downfall of the white race: white girlhood is often represented as the antithesis of criminality and white girls are the subjects most in need of protection. Yet when women had sex, particularly premarital sex, they embodied the opposite of the feminine ideal that was in need of protecting - they were transformed through behaviour into the figures society most needed to be protected from. ${ }^{56}$ If the ideal embodiment of personhood in the US was the white, landowning, father and husband, it is possible to see how lower-class women who had sex or men whose perceived disabilities rendered them incapable of capitalist productivity or land ownership were portrayed as legitimate targets for the justifiable nullification of their own reproductive capacities. ${ }^{57}$

There is a material reason for this fearmongering against women's promiscuity. Marxist feminist scholars have extended Friedrich Engels's argument in The Origin of the Family, Private Property, and the State that monogamy existed solely to preserve property and to ensure that land could be inherited..$^{58}$ Women's primary function in patriarchal capitalist families was to reproduce inheritors and serve the family with domestic labour. In an intensely privatized state like Kansas, reproductive control of lower-class women could serve as a form of enclosure that might prevent the possibility of too many potential inheritors. While white women may not have had access to formal citizenship rights like voting prior to 1920 (in Kansas, as early as 1912), they were under the protection of the law and were thus extended a measure of legal personhood although they were denied the full access to property ownership that white males enjoyed. For middle and upper-class "society women," many of whom championed for both the right to vote and for harsher laws governing sterilization, suffrage appeared to be a pathway to the fullest benefit of citizenship through self-ownership. ${ }^{59}$ Amidst eugenicists' concerns about the degradation of the white race, white supposedly feebleminded women not only threatened the sanctity of the status of property ownership and the right to vote, but they could also produce more feebleminded and "degenerate" white citizens. "Society women" who wanted to establish their citizenship through and against racialized people, criminals, and individuals with disabilities, did so by advocating for measures like sterilization, revealing that suffragists could advocate for state violence against those they deemed inferior to gain a greater sense of self-ownership. ${ }^{60}$

Considering the ways that Black and racialized populations have historically been deemed ineligible for personhood and treated accordingly, eugenic sterilization laws were imagined to function for the purposes of improving the white race and accommodated the reality that universal suffrage also meant that lowerclass women gained the right to property ownership. The state's vision did not always perfectly align with the stratified categories of citizenship that eugenicists imagined, although sterilization laws prove that that eugenics thinking certainly did 
become mainstream in the liberal state. ${ }^{61}$ This stratification of personhood is why sterilization laws could be applied wholesale to Black, Native, and Latinx populations across the US well into the twentieth century without widespread public condemnation, but assaults upon white youth were condemned by the media. ${ }^{62} \mathrm{~A}$ liberal eugenics state project then involved opening up categories of personhood to women via suffrage, while also creating conditional eligibility for full personhoodpersonhood could be granted to supposedly immoral women and lower-stock whites if they accepted institutionalization or sterilization as the price. ${ }^{63}$

The fight for women's suffrage and eugenic arguments have always been interrelated. Historians and disability studies scholars have discussed how middleand upper-class women advocating for their right to vote used dehumanizing propaganda to highlight the supposed hypocrisy of the fact that "lower class" men were able to vote while refined and educated women were not. ${ }^{64}$ Women were granted the right to vote in Kansas in 1912, the year before the first sterilization act was passed. What feminists might celebrate as an early accomplishment in the fight for women's right to equal political participation is sullied by the very terms in which women chose to argue their cause. Nicole Perry has documented the specific role that "society women" in Kansas played in both the suffrage movement and eugenics-informed reform projects in state institutions, linking the two, even if only tact ically. The same eugenicist arguments for why women of "good stock" should gain the right to vote against those deemed inferior were used by upper-class white women who championed for the rights of supposedly helpless people who could not care for themselves. Upper- and middle-class women were able to assert their political agency, and bolster their case for liberal citizenship, by sympathetically emphasizing the inferiority of others. Perry shows how this was always a racialized project for white women, as "the language of racial progress and inherent capacity for self-governance among whites informed women's understandings of themselves in Kansas. ${ }^{\prime 65}$

Upper-class, Kansas society women can be credited with bringing about the changes to state sterilization laws that would eventually lead to the more widespread use of the practice, efforts that increased following the rape and murder of nine-year-old Topeka resident Edna Dinsmore by repeat offender Fred Bissell in 1916. Just days after the crime, the Topeka Daily Capital, in a story titled "Prevention of Crimes like Bissell's," identified a question already on many people's mind: how could such a crime occur while sterilization laws existed and Bissell had been previously incarcerated for sex crimes? The author states that in the days following Bissel's latest crime, "many have been heard to denounce the law and censured lawmakers because of the deed of Bissell, the degenerate, was not made impossible. Many have clamored for a sterilization law as a cure-all and censured Legislators because of the lack of such a law." ${ }^{66}$ Dinsmore's murder did eventually lead to "reformed" sterilization laws; for example, 1917 revisions to the law were celebrated in the March 16 issue of the Chanute Daily Tribune as "one of the most progressive 
laws passed in Kansas in years." The same article explained that in the year following Dinsmore's murder, club women "resolved to carry out the motto, 'Avenge the death of Edna Dinsmore"," saying that "the sterilization bill was their weapon. They waged a long difficult fight — and they won. Their efforts will be of benefit to oncoming generations." ${ }^{67}$ Therefore, society women may not have been the only people in the state advocating for harsher sterilization laws, but they took the cause up in the hopes of preventing future crimes.

Only two decades later, the public reacted quite differently to the sterilization law being used against students in the Girls' Industrial School. The ways that white girlhood was deployed in the media during these two events reveals the contradictions between how the liberal eugenic state viewed sterilization as a means of protecting motherhood from degradation whereas many members of the public believed that sterilization laws were a mechanism to protect innocent white girls from criminality. Molly Ladd-Taylor illuminates these contradictory aims of sterilization laws when she argues that "the symbolic power of the innocent child depended on the opposing image of the wicked or 'defective' child, often represented as a darkened, sexualized throwback to a primitive past." ${ }^{68}$ It is no surprise that these representations conflicted, at times, in the media, creating confusion about who precisely these laws existed to protect. The national attention that the 1937 sterilization scandal at Beloit garnered is inherently racialized even when race is not named-the supposed innocence of what Robin Bernstein calls "angelic white children" was deployed for sympathetic purposes even if school officials simultaneously viewed the "incorrigible" and "feeble-minded" girls at the Girls' Industrial School as unreformable. The following section will detail the ways that these racialized logics operated within the institution and the state more broadly to deem white subjects reformable against students of colour.

\section{Racialization and Reformable Subjects}

Constructions of criminality and personhood within the Girls' Industrial School reveal the extent to which residents of colour were cast as inherently deviant whereas white residents could potentially be brought into the fold of reformability. Because white girlhood is often represented as the antithesis of criminality, the public expressed horror and outrage when white girls were treated in the same ways that those "deserving" of sterilization-like people of colour and people with cognitive disabilities - were treated. The campaign at the Girls' Industrial School at Beloit garnered local and national outrage because the victims of this particular campaign were the imagined white reformable female child. While institutional and state records provide evidence of administrators' scorn toward the so-called incorrigible youth housed at the facility, in the media the public reacted strongly to abuses inflicted on what Robin Bernstein describes as "angelic white children." ${ }^{69}$ Racialized representations of sexuality and deviance among students of colour at the Girls' Industrial School, were crucial in creating the white imagined reformable subject. 
Though Beloit was a predominantly white institution in a predominantly white region of the state, the assumed inherent criminality of racialized students provided a justification for the further abuse of students in general. Although internal institutional documents described general problems related to the pathologized, supposedly socially deviant and feebleminded criminal youths at Beloit, and although the residents at the school were discussed according to such representations, the "angelic white child" could be deployed rhetorically as a means of stripping rights from the so-called "colored" residents of Beloit. Further, the occurrence of, as well as the fear of, interracial sexual relationships at the school served to both further penalize the students of colour in the facility and also to mark those white students who participated in such interracial same-sex relationships as more deviant than their other white peers.

Constructions of criminality are premised on the differential access to legal and social personhood offered to differently racialized populations. Black women's racialized criminality was inherently tied to their gender and sexuality, as constructions of Black hypersexuality amplified the gender-based violence that these women and girls faced in state institutions. Historically as well as in the contempor ary carceral moment, "mythologies about Black female lasciviousness, dishonesty, and purported predisposition toward criminally violent behavior" worked in tandem with biased justice." ${ }^{70}$ In an institution where Black students were present but segregated from white students, assumptions about inherent criminality and racialized sexual deviancy were applied to girls of colour, and this created circumstances of increased policing for these students specifically as well as for the student population in general. ${ }^{71}$

While the school was integrated at the turn of the twentieth century, until the 1914-16 biennial report there existed only statistical evidence of Black girls and students of colour at the school. This changed in 1916, when superintendent Rebecca Wilson's report for the preceding two years explained that among the student body "very few of the white girls...have needed much correction. I wish I could say the same of the colored girls. We have had a few very serious problems among our colored girls." 72 These racist claims emphasizing the ways that the "colored" students negatively influenced the supposedly less deviant white students seemed to be, in part, a tactical means of securing funds to build a segregated cottage. Wilson wrote that the "problems" among the girls of colour would persist "as long as the colored girls are permitted to live with the white girls," 73 and asked for $\$ 25,000$ in funds from the state to build a separate cottage for "colored" students. But the notion that "very few of the white girls...needed much correction" is worth interrogating. This tone is not in keeping with the ways that previous superintendents had described the girls who came to them at the school. For instance, just two years earlier the same superintendent had noted that "some girls are sent to us without a stain or blemish, society having condemned their parents as unfit to raise them. Other girls, through neglectful, vicious, or incompetent parents come to us almost 
saturated with vice." 74

Superintendent Wilson stoked public fears of racial mixing, drawing upon the rhetoric of the "angelic white child" to acquire additional funds for the school. However, the 1916-18 biennial report provided a detailed account of the types of punishments that were used for "incorrigible" girls — punishments that ranged from corporal to solitary confinement, to "hair clipping"75 — and state investigations into abuse at the school in the 1930s and 1940s noted that punishments were applied widely-thus not confined to one racial category. Wilson's reliance upon the trope of Black students' inherent deviance was not only a means of garnering financial support from the state to build segregated housing, but was also operative in reaffirming the humanity and reformability of white students at the school. Superintendent Wilson condemned the corrupting influence of "colored students," claiming that they were the primary source of criminal behaviour at the school. Yet Wilson wrote elsewhere that "the spirit of the School [sic] is not that of a prison, but of a home." ${ }^{76}$ Under Wilson's control of the institution, it appears that it was the presence of the inherently-criminalized, "colored" girls that made Beloit a penal institution rather than a home.

In later decades, the allegation of a sexual relationship with a person of colour was apparently grounds enough for commitment or sterilization. When congressperson Kathryn O'Loughlin McCarthy uncovered the sterilization campaign at the Girls' Industrial School in 1937, she obtained information regarding 40 of the 62 Beloit girls who were sterilized between 1935 and 1936. In the small sample available, there is no evidence that the sterilization campaign at the Girls' Industrial School was enacted as a means of population control for girls of colour-only three on the list have the word "colored" printed below their names. ${ }^{77}$ What is evi dent, however, is the reality that sexual or familial contact with men of colour was grounds enough for sterilization. While a majority of the girls' offenses were listed as behavioural issues - incorrigible, immoral, or lazy — one girl's offense was listed as "incorr., asso. with Mex. men runs away." 78 There is undoubtedly a long history of white supremacist moral panic about white women and interracial sexual relationships, and this sterilization record reveals how these operations were usednot only as punitive measures to police appropriate gender behaviours, but also as a means of policing perceived sexual racial transgressions. ${ }^{79}$ That such practices could be given as justification for sterilization were unsurprising, as "from the 1860 s through the 1960 s, the American legal system elevated the notion that interracial marriage was unnatural to commonsense status." 80 While evidence of female sexuality provided grounds for students to be committed to reformatories, any suggestion of sexual racial transgression was evidence enough, in this account, to warrant sterilization.

Racialized individuals at the Girls' Industrial School were viewed as inherently criminal through the way that the school policed sexual relationships across racial lines. Mary Zaborskis describes how, in girls' reformatories, "black girls were 
seen as having an innate capacity for sexual deviance, and they had to be prevented from acting on their perceived nature." ${ }^{\text {"1 }}$ At the Girls' Industrial School, fears of Black sexuality were heightened by the fact that girls of different races lived in close proximity to one another. This is evident in testimony given to a 1945 state investigation into abuse at the school. In this account, Superintendent Grace Miles attests to the strange-but apparently widespread — phenomenon of girls cutting their lovers' initials into their skin. The house manager of the racially segregated West Cottage — whose introduction to her testimony is labeled "Statement by Mrs. Tracy Mitchell Thompson (colored)" 82 — provides a bit more context into the outcry over the phenomenon, highlighting how the practice occurred between white and Black girls. When asked by the interviewer "have you experienced any difficulty between the colored and the white girls here?" Thompson answered: "no, not unless you would call being too much in love with each other trouble. They do have that tendency, and it is not unusual... The white children are the aggressors. I think it is due to the fact that sometimes they think the negro child is mistreated." 83 Subversively, Thompson flipped the script regarding racialized assumptions of Black hypersexuality — she made sure to note that the white students were the sexual aggressors. She also downplayed the seriousness of these sexual relationships when she initially answered "no, not unless you would call being too much in love with each other trouble." We can see how she resisted the dominant assumption that Black girls were sexually aggressive and sexually deviant.

Thompson's interview also described the ways that students of colour were further penalized by being prevented from accessing the core of the reform that the "industrial" school supposedly had to offer: industriousness. ${ }^{84}$ Of the segregated unit, Thompson explained how

I really don't think our work program is intensive enough...You folks understand that we are in an isolated community and that there are no negroes around in a radius of perhaps seventy or a hundred miles, and our help is often drawn from people who are not used to living with the negro children, and of course that ele ment comes in, and right now I don't have very many girls out on detail..$^{85}$

Because Black students were apparently unwelcome in the larger Beloit community, the students of colour were prevented from having work detail. The exclusion from work may not have been wholly negative_a 1933 state-sanctioned investigation into conditions at social welfare institutions in Kansas noted that "the industrial act ivities, instead of being chiefly instructional to serve the welfare of the girls, are conducted to serve the institution with cheap labor." 86 The issue, however, was not that the students of colour did not have access to the same opportunities for labour exploitation that the white students had. The core of the issue was who was deemed 
reformable and granted access to stratified citizenship via labour. In a failed attempt at sympathy, the same 1933 report confirmed the notion that students of colour were not reformable subjects when it noted that "the colored girls are housed in a separate cottage. Their vocational training is criminally neglected, although it must be remembered that the plurality of these girls can only hope to earn an honest living as servants." ${ }^{87}$ The white students were, at the end of the day, subjects who could be reformed through hard labour, while the students of colour were merely tucked away from society and kept segregated from the rest of the student body.

While a general sense of hopelessness about the futures of the feebleminded and oversexed youth at the school pervades this 1933 report as well as a number of official and unofficial investigations into the school, the reports also show how students of colour were shown to be inherently criminal or deviant. This reveals why the Girls' Industrial School was the only site in Kansas that attracted large-scale outcry about sterilization at the height of the practice's popularity across the statewhite girlhood and angelic white childhood, when represented as such-demonstrates that the subject is ultimately reformable. While institutional documents reveal that, within the institution the students were not regarded as deserving of motherhood, segregation at the Girls' Industrial School demonstrates how there still remained a hierarchy in determining who was capable of being reformed through labour after their term at Beloit, and whose inherent racialized criminality deemed them unworthy of reform. 


\section{NOTES}

1 "Sterilization of 62 Girls in Home Upheld," New York Daily News, 30 October $1927,150$.

2 "Sterilizing Girls Scored" Los Angeles Times (1923-Current File), 24 October 1937, 16.

${ }^{3}$ Board of Control of the State Charitable Institutions of Kansas, Sixth Biennial Report of the Board of Control of the State Charitable Institutions of Kansas (Topeka, 1916), 7.

${ }^{4}$ See C.B. MacPherson, The Political Theory of Possessive Individualism: Hobbes to Locke (Oxford: Oxford University Press, 1962) for an analysis of the centrality of property ownership to liberal understandings of individuality.

${ }^{5}$ See Cheryl I. Harris, "Finding Sojourner's Truth: Race, Gender, and the Institution of Property," Cardozo Law Review 18, no. 2 (November 1996): 348, which describes how "white women's exclusion from property and other rights was ideologically grounded on the separation of the public and private spheres, the latter being the domain to which women were consigned. They were not outside of civil society and were in fact a part of the community; however, they were not autonomous individuals but a subordinate part of the male-headed family."

${ }^{6}$ See Nicole Perry, "Diseased Bodies and Ruined Reputations: Venereal Disease and the Constructions of Women's Respectability in Early 20th Century Kansas" (PhD Dissertation, University of Kansas, 2015) for a history of white women's act ivism in both voting rights movements and eugenic movements.

${ }^{7}$ Wendy Kline, Building a Better Race: Gender, Sexuality, and Eugenics from the Turn of the Century to the Baby Boom (Berkeley: University of California Press, 2001), 106, discusses how in the 1930s eugenicists "further popularized their goal to improve civilization by making reproduction a social and medical responsibility rather than an individual right."

${ }^{8}$ My understanding of the "legal imaginary" is inspired by Colin Dayan, The Law Is a White Dog: How Legal Rituals Make and Unmake Persons (Princeton, NJ: University of Princeton Press, 2011). Dayan explains that "In its manipulation of categories such as the spirit and the flesh, the law perpetuates its claims to mastery and comprehension, all the while investing the juridical order with the power to redefine persons. Legal culture has carved up human differences into hierarchies capacious enough to accommodate subordination. The law's artificial entities - whether disabled as slaves or degraded as felons_-are made 'vulnerable,' in the scholar and act ivist Ruthie Gilmore's words, to 'premature death' (62).:

${ }^{9}$ Sarah Haley, No Mercy Here: Gender, Punishment, and the Making of Jim Crow Modernity (Chapel Hill: University of North Carolina Press, 2017), 5.

${ }^{10}$ Although the schools existed as both carceral and educational spaces, I use the word "student" rather than "inmate" to refer to residents of the Girls' Industrial 
School and similar institutions as a more humanizing term.

${ }^{11}$ Harriet C. Frazier, "The State Industrial School for Girls at Beloit, Kansas: The First 50 Years, 1889-1939," November, 1988, Paper presentation, Chicago Meeting of the American Society of Criminology 8, Locator 97-5-2-11, Kansas State Historical Society, Topeka, KS.

${ }^{12}$ Frazier, "The State Industrial School for Girls at Beloit, Kansas," 7.

${ }^{13}$ Department of the Interior, Census Office, "Table 5, Population of States and Territories by Minor Civil Divisions, 1880-1890," Report of the Population of the United States at the Eleventh Census, 1890 (Washington, DC, 1890), 150.

https://www.census.gov/prod/www/decennial.html.

${ }^{14}$ Frazier, "The State Industrial School for Girls at Beloit, Kansas," 8-10.

${ }^{15}$ United States Department of Commerce, "Part 3: Kansas," Volume II: Characteristics of the Population, Sixteenth Census of the United States, 1940 (Washington, DC, 1940), 41, https://www.census.gov/prod/www/decennial.html.

16 "Beloit City Council," Beloit Gazette, 10 May 1879, 3. For more on the history of the Exoduster movement see Nell Irvin Painter, Exodusters: Black Migration to Kansas after Reconstruction (New York: W.W. Norton, 1976).

${ }^{17}$ In Brent Campney, This is Not Dixie: Racist Violence in Kansas, 1861-1927 (Champaign, IL: University of Illinois Press, 2015), Campney describes the law's passage as evidence of a "de jure sundown policy" (79).

${ }^{18}$ State Board of Charities, Fourth Biennial Report of the State Industrial School for Girls, Beloit (Topeka, KS, 1896), 150, https://cdm16884.contentdm.oclc.org/digital/collection/p16884coll111/id/1/rec/1.

${ }^{19}$ Girls' Industrial School, Eighth Biennial Report of the State Industrial School for Girls at Beloit (Topeka, 1904), 17, https:/ /cdm16884.contentdm.oclc.org/digital/collection/p16884coll111/id/1/rec/1.

${ }^{20}$ State Board of Administration, Twenty-Fifth Biennial Report of the Girls' Industrial School, Beloit (Topeka,KS, 1938), 27, https://cdm16884.contentdm.oclc.org/digi$\mathrm{tal} /$ collection/p16884coll111/id/1/rec/1. Aside from the 1896 report, the earliest available racial demographic data I could locate was from the school's 1898-1900 biennial report, which lists seventeen residents as "black." In Girls' Industrial School, Sixth Biennial Report of the State Industrial School for Girls at Beloit (Topeka, KS, 1900), 14-15, https:/ / cdm16884.contentdm.oclc.org/digital/collection/p16884coll111/id/1/rec/1.

${ }^{21}$ For discussions of how black girls were read as inherently criminal in state carceral institutions, see Sarah Haley, No Mercy Here; and Karin L. Zipf, Bad Girls at Samarcand: Sexuality and Sterilization in a Southern Juvenile Reformatory (Baton Rouge: Louisiana State University Press, 2016), 170-172.

${ }^{22}$ State Board of Administration. Twentieth Biennial Report of the Girls' Industrial School, Beloit, Kansas (Topeka, 1928). https://cdm16884.contentdm.oclc.org/digi- 
tal/collection/p16884coll111/id/1/rec/1.

${ }^{23}$ Ruth M. Alexander, The "Girl Problem": Female Sexual Delinquency in New York, 1900-1930 (Ithaca, NY: Cornell University Press, 1995), 10.

${ }^{24}$ Michael A. Rembis, Defining Deviance: Sex, Science, and Delinquent Girls, 1890-1960 (Urbana: University of Illinois Press, 2011), 32.

25 Alexander, The "Girl Problem," 34. For more about the history of girls' reform schools and women's incarceration in the US see also Barbara M. Brenzel, Daughters of the State: A Social Portrait of the First Reform School for Girls in North America, 1856-1905 (Cambridge: The Massachusetts Institute of Technology, 1983); Estelle B. Freedman, Their Sisters' Keepers: Women's Prison Reform in America, 1830_ 1930 (Ann Arbor: The University of Michigan Press, 1981). For a history of race and youth incarceration see Annette Louise Bickford, Southern Mercy: Empire and American Civilization in Juvenile Reform, 1890-1944 (Toronto: University of Toronto Press, 2016).

${ }^{26}$ For discussions about how eugenic categories of mental inferiority were overapplied to people of colour, specifically in the case of Mexicans and Mexican Americans, see Natalie Lira, "Mexican Americans and Eugenic Sterilization: Resisting Reproductive Injustice in California, 1920-1950," Atrlan: A Journal of Chicano Studies 34, no. 2 (Fall 2014), 9-34; Chávez-García, "Mildred S. Covert: Eugenics Fieldworker, Racial Pathologist" in States of Delinquency: Race and Science in the Making of California's Juvenile Justice System (Berkeley: University of California Press, 2012), 79-111; Alexandra Minna Stern, "Quarantine and Eugenic Gatekeeping on the US-Mexico Border" in Eugenic Nation: Faults and Frontiers of Better Breeding in Modern America (Berkeley: University of California Press, 2005), 57-81. For a historical account of "feeblemindedness" as a social and medical category see Molly Ladd-Taylor, "Who Was Feebleminded? in Fixing the Poor: Eugenic Sterilization and Child Welfare in the Twentieth Century (Baltimore, MD: Johns Hopkins University Press, 2017), 84-116. While some scholars have discussed feeblemindedness as a catch-all term that allowed women to be incarcerated for defying sexual norms, Ladd-Taylor argues that "Although some women designated feebleminded may have been resisting the norms of a repressive society, many others were victims of rape, incest, or domestic violence, or came from troubled families unable or unwilling to support their adolescent daughters" (100-101). For a discussion of how the designation of "feeblemindedness" was overapplied to women of working-class backgrounds or women incarcerated for sex work see Rembis, Defining Deviance, 22-23. See Scott W. Stern, The Trials of Nina McCall: Sex, Surveillance, and the Decades-Long Government Plan to Imprison "Promiscuous Women" (Boston: Beacon Press, 2018), 89-90. See Adam Cohen, Imbeciles: The Supreme Court, American Eugenics, and the Sterilization of Carrie Buck (New York: Penguin Press, 2016) for a detailed account of how the plaintiff in the US Supreme Court case Buck v. Bell, Carrie Buck, was categorized as mentally inferior in part 
due to socioeconomic factors.

${ }^{27}$ For a history of the use of labour in American Indian boarding schools see "Working for the School," in Brenda J. Child, Boarding School Seasons: American Indian Families, 1900-1940 (Lincoln, NE: University of Nebraska Press, 1998), 6986; and Kevin Whalen, Native Students at Work: American Indian Labor and Sherman Institute's Outing Program, 1900-1945 (Seattle and London: University of Washington Press, 2016). For a comparative look at black and American Indian education in the nineteenth and twentieth centuries in Kansas, see Kim Cary Warren, The Quest for Citizenship: African American and Native American Education in Kansas, 18801935 (Chapel Hill: The University of North Carolina Press, 2010). For a critical discussion of the modes of extraction and accumulation employed at Hampton and Haskell, read Sarah E.K. Fong, "Racial-Settler Capitalism: Character Building and the Accumulation of Land and Labor in the Late Nineteenth Century," American Indian Culture and Research Journal 43, no. 2 (Spring 2019), 25-48.

${ }^{28}$ Roderick Ferguson, "Of Our Normative Stirrings: African American Studies and the Histories of Sexuality," Social Text 23 no. 3-4 (Fall-Winter 2005), 92. ${ }^{29}$ For an account of the way that the regulatory technologies of labour management in industrial settings developed alongside and in collusion with theories and practices of race management, see David Roediger and Elizabeth Esch, The Production of Difference: Race and The Management of Labor in US History (New York: Oxford University Press, 2012).

30 Alexander, The "Girl Problem," 40.

${ }^{31}$ Frazier, "The State Industrial School for Girls at Beloit, Kansas," 14.

${ }^{32}$ Meeting of Citizens Committee at State Industrial School for Girls at Beloit, Kansas: Official Transcript, August 24, 1945, Department of Social and Rehabilitation Services Historical Files, Locator 59-08-04-11, (box 2), 72 Kansas State Historical Society, Topeka, KS.

${ }^{33}$ Public Welfare Temporary Commission, Report of the Public Welfare Temporary Commission, State of Kansas, Appointed by Governor Harry H. Woodring, 1931-1933, (Topeka, KS,15 January 1933), 102, https:/ / babel.hathitrust.org/cgi/pt?id=mdp.39015028059684\&view=1 up\&seq= 5.

34 Cohen, Imbeciles, 284-285.

35 “Sterilizing Girls Scored," Los Angeles Times, 24 Oct. 1937, 16.

${ }^{36}$ State Board of Administration, Twenty-fourth Biennial Report for the Girls' Industrial School, Beloit, Kansas (Topeka, 1936), 5-6.

https://cdm16884.contentdm.oclc.org/digital/collection/p16884coll111/id/1/re c/1.

37 Twenty-Fourth Biennial Report, 5-6.

${ }^{38}$ Mark A. Largent, Breeding Contempt: The History of Coerced Sterilization in the United States (New Brunswick, NJ: Rutgers University Press, 2011), 22. 
${ }^{39}$ Julius Paul, "Three Generations of Imbeciles Are Enough...": Eugenic Sterilization Laws in American Thought and Practice (Washington, DC: Walter Reed Army Institute of Research, 1965), 617, https:// readingroom.law.gsu.edu/cgi/viewcontent.cgi?article $=1097 \&$ context $=$ buckvbell.

40 "Mutilation: By the Wholesale Practiced at the Asylum," The Wichita Star, 1 September 1894, 9.

${ }^{41}$ F.C. Cave, "Report of Sterilization in the Kansas State Home for Feeble Minded," Journal of Psycho-Asthenics XV, nos. 3 and 4 (March and June, 1914), 2. Accessed in The Menninger Archives at the Kansas State Historical Society. ${ }^{42}$ Harry H. Laughlin, Psychopathic Laboratory of the Municipal Court of Chicago, Eugenical Sterilization in the United States (Chicago, 1922), 29, https:/ / repository.library.georgetown.edu/bitstream/handle/10822/556984/EugenicalSterilizationInTheUS.pdf.

${ }^{43}$ Laughlin, Euginical Sterilization in the United States, 30.

${ }^{44}$ Sixth Biennial Report of the Board of Control of the State Charitable Institutions of Kansas, 7. See also Paul, "Three Generations of Imbeciles are Enough," 618, where the author describes the reasons that heads of institutions did not use the 1913 statute.

${ }^{45}$ Laughlin, Engenical Sterilization in the United States, 72.

${ }^{46}$ Laughlin, Engenical Sterilization in the United States, 72.

${ }^{47}$ Laughlin, Eugenical Sterilization in the United States, 12.

${ }^{48}$ Paul, Three Generations of Imbeciles are Enough, 619.

${ }^{49}$ Judge Burch's decision is quoted in Norman St. John-Stevas, Life, Death, and the Law: Law and Christian Morals in England and the United States (Washington, DC:

Beard Books, 1961),168.

${ }^{50}$ Paul, Three Generations of Imbeciles are Enough, 620.

${ }^{51}$ Franklin D. Roosevelt Club Resolution, 3 November 1938, Kathryn (O'Loughlin) McCarthy Papers, 1900-1948, microfilm, Kansas State Historical Society, MS 1752, section 12 .

52 “Letter from Mr. John A. Johnson," 24 October 1937, Kathryn (O’Loughlin) McCarthy Papers, 1900-1948, microfilm, Kansas State Historical Society, MS 1752, section 11 .

${ }^{53}$ Laughlin, Eugenical Sterilization in the United States, 73.

${ }^{54}$ Laughlin, Eugenical Sterilization in the United States, 344.

${ }^{55}$ See Kline, Building a Better Race, 114-115 for a discussion of how "as eugenicists were beginning to argue in the 1930s, an inadequate environment-not just a pathological defect—could and did damage a child."

${ }^{56}$ See Louise Michele Newman, White Women's Rights: The Racial Origins of Feminism in the United States (New York: Oxford University Press, 1999), for a discussion of social evolutionary theories in the 1870 s that spawned the eugenics 
movement. Newman states that "many male theorists in this period argued that (white) women's biological conservatism ... held her responsible for retarding the evolutionary development of the white race" (50).

${ }^{57}$ Cheryl I. Harris, "Whiteness as Property," Harvard Law Review 106, no. 8 (June 1993), 1725-1728. Harris discusses the centrality of whiteness and property ownership to the establishment of the US state.

${ }^{58}$ See Friedrich Engels, "The Monogamous Family," in The Origin of the Family, Private Property, and the State (Chicago: Charles H. Kerr \& Company, 1908), 75101. Accessed at https://www.gutenberg.org/files/33111/33111-h/33111h.htm\#Page_35. For an example of feminists' extension of Engels's argument, see Janet Sayers, Mary Evans, and Nanneke Redclift, eds., Engels Revisited: New Feminist Essays (London: Tavistock, 1987).

${ }^{59}$ See Rembis, Defining Deviance, for a discussion of how white women as "maternalist reformers" were socially empowered through their participation in eugenics campaigns, and how "throughout the nineteenth century, middle-class white women increasingly extended their role as wife and mother - a role that the dominant Anglo-American culture imbued with reformative capacities-beyond their own homes" (14).

${ }^{60}$ Aileen S. Kraditor, The Ideas of the Woman Suffrage Movement, 1890-1920 (New York: Columbia University Press, 1965) explains how "when [the suffragists] demanded the vote on the basis of justice and the consent of the governed, they could not intend absolutely universal suffrage, which would have given the vote to every human being. Having conceded that women, lunatics, and felons must be excluded, they had to define those categories. Such definitions, necessarily containing an element of arbitrariness, would have to be justified as serving the 'good of society, and other limitations of the franchise for the same reason would appear logical enough" (253-254).

${ }^{61}$ While many scholars connect sterilization laws to the popularity of eugenics in the early to mid-twentieth century, Molly Ladd-Taylor looks at sterilization from a social welfare perspective. In Molly Ladd-Taylor, Fixing the Poor Ladd-Taylor argues that "the policy's actual design and administration over the years were equally shaped by a longer-term concern with limiting the state's responsibility for the poor" (2).

${ }^{62}$ Susan K. Cahn, Sexual Reckonings: Southern Girls in a Troubling Age (Cambridge, MA: Harvard University Press, 2007), 158-159 says "the racial practice and discourse of sterilization formed first and most explicitly around young white women, whose victimization on the basis of race and class formed a precedent for later sterilizations of young black women."

${ }^{63}$ For context about this argument, see Newman, White Women's Rights, 58, that states "By situating the debates over woman suffrage in the context of evolution and racial progress, it becomes clear that the prosuffrage arguments were not 
simply about the right of woman to vote, but about ... the future progress of Anglo-Saxons as a race."

${ }^{64}$ See Douglas Baynton, "Disability and the Justification for Inequality in America," in The New Disability History, ed. P.K. Longmore and L. Umansky (New York: New York University Press, 2001), where he describes that "A popular theme in both British and American suffrage posters was to depict a thoughtful-looking woman, perhaps wearing the gown of a college graduate, surrounded by slopebrowed, wild-eyed, or 'degenerate' men identified implicitly or explicitly as 'idiots' and 'lunatics.' The caption might read 'Women and her political peers' or 'It's time I got out of this place. Where shall I find the key?' (40)"

${ }^{65}$ Perry, "Diseased Bodies and Ruined Reputations," 130.

66 "Preventions of Crimes like Bissell's," The Topeka Daily Capital, 2 May 1916, 4. 67 “The Sterilization Bill,” Chanute Daily Tribune, 16 March 1917, 2.

${ }^{68}$ Ladd-Taylor, Fixing the Poor, 25.

${ }^{69}$ Robin Bernstein, Racial Innocence: Performing American Childhood from Slavery to Civil Rights (New York: New York University Press, 2011), 16.

${ }^{70}$ Kali N. Gross and Cherry D. Hicks, Cheryl, "Introduction-Gendering the Carceral State: African American Women, History, and the Criminal Justice System," Journal of African American History 100, no. 3 (July 2015), 359.

${ }^{71}$ For further discussions of the ways that racialized notions of criminality work to further carceral logics and state power more broadly, see Lisa Marie Cacho, Social Death: Racialized Rightlessness and the Criminalization of the Unprotected (New York: New York University Press, 2012); Ruth Wilson Gilmore, Golden Gulag: Prisons, Surplus, Crisis, and Opposition in Globalizing California (Berkeley: University of California Press, 2007); Dylan Rodríguez, Forced Passages: Imprisoned Radical Intellectuals and the US Prison Regime (Minneapolis: University of Minnesota Press, 2006); and Kelly Lytle-Hernández, City of Inmates: Conquest, Rebellion, and the Rise of Human Caging in Los Angeles, 1771-1965 (Chapel Hill: University of North Carolina Press, 2017).

${ }^{72}$ Board of Corrections, Fourteenth Biennial Report of the state Industrial School for Girls, (Topeka, KS, 1916), 4. https://cdm16884.contentdm.oclc.org/digital/collection/p16884coll111/id/1/rec/1.

${ }^{73}$ Board of Corrections, Fourteenth Biennial Report, 4.

${ }^{74}$ Board of Corrections, Thirteenth Biennial Report of State Industrial School for Girls (Topeka, KS, 1914), 3. https://cdm16884.contentdm.oclc.org/digital/collection/p16884coll111/id/1/rec/1.

${ }^{75}$ State Board of Administration, Fifteenth Biennial Report for the Girl's School at Beloit (Topeka, KS, 1918), 4. https://cdm16884.contentdm.oclc.org/digital/collection/p16884coll111/id/1/rec/1.

${ }^{76}$ Thirteenth Biennial Report of State Industrial School for Girls, 3. 
${ }^{77}$ Kansas Girls' Industrial School sterilization records, 1935-1936, Kathryn (O'Loughlin) McCarthy Papers, 1900-1948, microfilm, Kansas State Historical Society, MS 1752, section 12. I could unfortunately not locate a statistical overview of the race or ethnicities of Kansas sterilization victims in the archives, so I do not have a broad view of the extent to which the procedure was disproportionately used against people of colour in Kansas. For a cumulative total of the number of sterilizations in Kansas and a breakdown by gender see Paul, "Three Generations of Imbeciles are Enough," 627. For critical histories of the usage of sterilization against women of colour throughout the twentieth and twenty-first centuries see Angela Y. Davis, "Racism, Birth Control and Reproductive Rights" in Women, Race, and Class (New York: Vintage Books, 1981), 172-200; Harriet A. Washington, Medical Apartheid: The Dark History of Medical Experimentation on Black. Americans from Colonial Times to the Present (New York: Anchor Books, 2008); Laura Briggs, Reproducing Empire: Race, Sex, Science, and US Imperialism in Puerto Rico (Berkeley: University of California Press, 2002); and No Más Bebés, directed and produced by Renee Tajima-Peña, produced by Virginia Espino (San Francisco: ITVS, 2015). ${ }^{78}$ Kathryn (O'Loughlin) McCarthy Papers 1900-1948. Section 12. Sterilization at Beloit- Notes, Articles, Etc., Kansas State Historical Society.

${ }^{79}$ See Peggy Pascoe, What Comes Naturally: Miscegenation Law and the Making of Race in America (New York: Oxford University Press, 2009), 106 for a discussion of how interracial sexual relationships were deemed inherently illicit.

${ }^{80}$ Pascoe, What Comes Naturally, 3.

${ }^{81}$ Mary Zaborskis, "Queering Black Girlhood at the Virginia Industrial School," Signs: A Journal of Women in Culture and Society 45, no. 2 (January 2020), 382.

${ }^{82}$ Meeting of Citizens Committee at State Industrial School for Girls at Beloit, 66. Rembis, Defining Deviance, 106-107 also describes reports of similar self-harming behaviour at the Illinois State Training School for girls in Geneva.

${ }^{83}$ Meeting of Citizens Committee at State Industrial School for Girls at Beloit, 73-74. Rembis, Defining Deviance, 103-105 describes anxieties about the nature of relationships between black and white students at the Illinois State Training School for girls in Geneva.

${ }^{84}$ For a wonderful account of the way that labour was used as a facet of regulating heterosexuality in an African American girls' industrial school in Virginia, see Zaborskis, "Clean, Queer, and Under Control: Contaminated Sexualities in African American Boarding Schools," in Erotics of Education: Queering Children in Nineteenth and Twentieth Century Boarding Schools (PhD Dissertation, University of Pennsylvania, 2017). Zaborskis explains, for instance, "the manual labor for which industrial schools had trained students required a commitment to sexual propriety; to be a laborer was to embody and enact respectability, which was coded as heterosexual" (230-231).

${ }^{85}$ Meeting of Citizens Committee at State Industrial School for Girls at Beloit, 
72.

${ }^{86}$ Report of the Public Welfare Temporary Commission, 102.

${ }^{87}$ Report of the Public Welfare Temporary Commission, 99. 